\title{
An Analysis of Injustice as Dimension of Poverty in the Pakistan's Perspective
}

\author{
Muhammad Sohail Anwar \\ $\mathrm{PhD}$ Scholar \\ Faculty of Management Studies, University of Central Punjab, Lahore \\ Qais Aslam $(\mathrm{PhD})$ \\ Faculty of Management Studies, University of Central Punjab, Lahore \\ Faisal Mustafa $(\mathrm{PhD})$ \\ Dean, Faculty of Management Studies, University of Central Punjab, Lahore
}

\begin{abstract}
Pakistan's Vision 2025 demonstrates to improve the economic growth and eradicate poverty. It is observed from literature that poverty has different dimensions, it cannot be limited to monetary deprivation but it should have extended to all its possible dimensions. In order to eradicate the poverty, it should be clearly defined in all aspects. In literature poverty is pronounced as multi-dimensional phenomenon, and also measured in different dimensions like health, education, living standard, and social and political aspects. In presence and discussion of these poverty dimensions, there is one important dimension of poverty which is commonly perceived but not yet discussed in literature. This missing aspect of poverty is lack of justice or injustice in society, this concept is so important that it is the root cause of all other problems. The objective of this research is highlight the judicial statistics in Pakistan, and to suggest that injustice also is dimension of poverty. For the comparison and elaborate the need of focusing on judicial problems, the secondary data obtained from the survey of more than 46000 people in 45 countries. It is observed that 80 to 89 percent of peoples involved in judicial process belong to top five countries; Pakistan is at second position among the selected 45 countries. Statistics show that $85 \%$ people in Pakistan involved in litigation process, this is alarming position in current scenario, and require much attention from policy makers and Government toward judicial sector. Public trust on Government institution shows the trust of people on their government, but this indicator is also poor in Pakistan, only 14 percent people use government institutes as $3^{\text {rd }}$ party in their disputes resolution. Justice should be quick in society, Pakistan is lowest in this ranking, and $67 \%$ of registered complaints are under litigation process. Here the underpinning question has been answered that either the injustice is the cause of poverty or poverty creates injustice. So it is concluded that to eliminate the poverty, it is prior condition to define the poverty in all its dimensions, access to justice is the fundamental right of people living in society, and is also the root cause of many other problems, so it should be included as the part of poverty when to define the poverty. A problem can only be solved, when it is defined in proper and complete essence.
\end{abstract}

Keywords: Poverty, Multi-Dimensional, Access to Justice

DOI: $10.7176 /$ JPID/51-02

Publication date: November $30^{\text {th }} 2019$

\section{Introduction 1}

There have been many technological and economic advantages achieved by countries of the world in the $20^{\text {th }}$ and the beginning of the $21^{\text {st }}$ Century. This new millennium is 19 years old, but still poverty remains a problem both for developed as well as developing countries. Researchers have explored that due to lack of the enforcement of rule of law, unequal economic opportunities, and other forms of exploitation and discrimination, poverty as a human and economic problem exists in many countries; therefore, it is important to determine and to solve issues of poverty in each nation(Zhou \& Liu, 2019). In this context, it is important to determine the dimensions of poverty and to pinpoint the indicators and factors behind each dimension of poverty(Khan \& Akram, 2018; Schwab, 2018).

As with the rise in world population and expansion in the concept of public welfare, it is widely recognized that deprivation in public facility is called poverty in that field(Ahmed et al., 2018). It is widely recognized that poverty is a multidimensional phenomenon, so when defining poverty, a distinction should be made between traditional and modern approach. In traditional approach poverty refers only to one dimension such as income or consumption, while in modern approach poverty is a multidimensional phenomenon and should be defined and resolved in all its dimensions. The concept of modern poverty approach constituted a clear breakthrough in the traditional concept of poverty (Fusco, 2003, p. 2).

Booth, 1893, 1902, p. 92 associate the poverty with the concept of basic needs approach, and introduced the economic concept of poverty by combining poverty line and head count ratio. Rowntree, 1908, p. 1associate the poverty by collecting information for housing, occupation, and earning. This was the breakthrough in poverty investigation, which have been followed with the numerous theoretical, empirical, and methodological 
improvements, that were solely relied on the same paradigm(Fusco, 2003, p. 4).Abel-smith \& Townsend, 1965, p. 14 concluded that poverty measurement through material approach (Income and Expenditure) do not predict the actual social condition, circumstances of poor household, these finding have not been compared with the average and wealthy peoples. So it is necessary to measure poverty in different ways, which shows the magnitude of inequality in the society(Khan \& Akram, 2018). Materialistic approach of poverty was followed by different researchers in different ways, however in 1970s it was criticized by empirical sociologist, this criticism was based on the results concluded in this approach. So it was perceived that poverty should be defined in different fields with different approaches. This concept later on divided into two further categories like capability approach and functioning approach.

Sen, 1976, pp. 221-227introduced the concept of poverty as a capability approach, which argues that wellbeing comes from a capability to function in society. He also suggested a two-step method of measuring poverty, (I) identification of the poor, and (II) aggregation of deprived indicators in all its dimensions. Townsend, 1979, pp. 57-58 mentioned that historical definitions of poverty expressed in absolute level of minimum needs, which is found to be inappropriate and misleading, because needs differ in different societies and in different periods. He introduced the concept of social exclusion and suggested to measure the social needs in subjective, collective and objective terms. Gaye et al., 2010, p. 5,12 suggested that poverty arises when people lack key capabilities, have inadequate income, low level of education, poor health facilities, insecurity, lack of nutrition, lack of voice, lack of capacity, lack of opportunity to improve one's life, sense of powerlessness and absence of rights such as freedom of speech are indicators of poverty.

In traditional approach poverty was associated with economic approach, which is called economic dimension of poverty. In economic dimension poverty is associated with poverty line, and a household having the income less than poverty line is declared as poor, but poverty line does not explain the depth of poverty. Therefore, it is recognized that poverty cannot be limited to income and expenditure approach, rather it should be extended to non-income dimensions (Bourguignon \& Morrisson, 2002; Zhou \& Liu, 2019). If poverty is multidimensional phenomenon, then the questions area rise what we mean a dimension and multidimensional? Indeed, the selection and choice of indicators about poverty in living condition is the fundamental step of multidimensional poverty measurement, and has a great importance for the policy implications. The questions we have to answer are; how many dimensions can we have? Is there a definite set of dimensions that can be constructed or are every possible dimension relevant in defining the multidimensionality of poverty?

It is the commonly perceived that basic human needs are health, education and housing, access to these basic facilities is the fundamental right of each individual(World Bank, 2018;Alkire \& Jahan, 2018). By the evolution of multi-dimensional concept, poverty measurement is extended to these dimensions, but one thing is common, either the poverty is measured in any dimension it must be due to economic poverty or can be the cause of economic poverty. In literature lack of health facilities is considered as a dimension of poverty(Neelsen et al., 2019). In health poverty a household is considered as poor if he deprives from basic health facilities, or lives in a condition when members of their family due to lack of access to health facilities dies, disease, hunger or violence(World Health Organization, 2018). This lacking health facilities may be due to lack of financial sources (Economic Poverty), or by spending some of its financial sources to access health facilities will push him into economic poverty(Chen et al., 2019).

In multi-dimensional concept of poverty, second dimension is measured by access to basic educational facilities, this is called as educational dimension of poverty(Alkire \& Jahan, 2018). In educational poverty a household is considered as poor if he has not access to basic educational facilities (World Bank, 2018). Education is the cheapest and strong defense of a nation, but in Pakistan down trodden position of educational level is an ample testimony of fact that it is unable to defend its own sector. Literacy rate is the representative of well-educated economy because; education gives knowledge of the world and changes it into something better, it also develops the perspective of looking at life(Phoenix, 1998, p. 2).

Education level is a tool of poverty elevation, all the countries have focusing to promote education and trying to provide all the facilities in this context. An economically poor person unable to access the basic educational facilities, unable to pay fee and therefore leave the education (Kavuri \& Shao, 2017, p. 4). When poor above poverty line spends some of its financial sources to access the educational facilities, it will suffer in economic poverty.

Thirdly literature shows deprivation is in the form of political poverty(Deveaux, 2018).United Nation, 2006established three areas of priority with regard to equality and equity; first, equality of rights which is elimination of all forms of discriminations, second, equality of opportunities, which requires stable social, economic, cultural, and political conditions third, equity in living conditions for all individuals and households.

Fourth, housing is third essential element of human need after health and education, which directly related to other issues such as employment, transportation, basic health and educational facilities(Alkire \& Jahan, 2018). World Health Organization, 2010proposed that healthy housing conditions are important for individuals as well as community health; composed of proper sanitation system, availability of decent toilets, and quality of 
construction material and availability of rooms for family members. When the communities have lack of access to these basic facilities, then there will be excess to health problems like diseases. A person when suffered in health related issues, it must require to spend some financial sources to reduce these problems. This spending is results in financial burden on household, and further cause of economic poverty(Neelsen et al., 2019).

There is some other dimension of poverty which has been discussed in literature. In literature social aspect of community are mentioned as social dimension of poverty (Deveaux, 2018). In social dimension households breeds on unacceptable behaviors, drug addiction, crime, prostitution and violence in family and community. In presence and discussion of these poverty dimensions, there is one important dimension of poverty which is commonly perceived but not yet discussed in literature. Marshal identifies the law of social life with the great moral law of justice, and, proving previous conclusions, shows how retrogression may be prevented and a grander advance begun. This missing aspect of poverty is lack of justice or injustice in society, this concept is so important that it is the root cause of all other problems(Kavuri \& Shao, 2017; World Justice Project, 2018; World Justice Report, 2019). Therefore, access to justice should be easy and available to all, social justice that is an essential virtue of institutions also positively influence on economic performance in any country and society. A well-established process of administration of justice guarantees the protection of basic human rights and supremacy of rule of law(Saguin, 2018). But statistics shows that a lot of people have been deprived in current justice system, most of them not go to register their claims due to a number of reasons, those who registered their claim have to face a lot of problem in litigation process like extra financial cost, wastage of time, complicated process and delay in decision, huge judicial backlog(Chen et al., 2019; Masood, 2018). Therefore, the access to justice was neither speedy nor easy for the citizens especially to poor.

Injustice in society also the prediction of poverty which should be researched and mentioned in along with major issues. In current justice system poor people have no access to justice, unable to protect their basic right, government institutes fail to compensate them against any violation of their rights, income and asset. Judicial dimension of poverty has further components like right to protection of person and property fall in civil law, safety of business matter in commercial law, social law deals with worker's protection and criminal law punishes criminals of serious offenses(Saguin, 2018). These are all interrelated and to overcome the judicial poverty enforcement of these laws is crucial. United Nation, 2012 concluded that there is only one way to defeat the poverty which is equal access to justice.

National Integrity System, 2014, p. 96mention that base foundation of a state is composed of 13 pillars and judiciary ranked third in them. Expeditious justice plays a key role in Governance of state: as like health and education it is the responsibility of state to provide quick and fair justice to its citizens, because it is the single way to provide remedy for effective persons against the violation of their basic rights. Basic human rights of poor are difficult to protect, because usually they are unaware to their rights and have no sources or access to safeguard or to secure these (World Justice Report, 2019). Situation becomes more harmful for the poor when they are unable to get remedy against the violation of their human and legal rights. In addition, the poor have to face the problem of limited legal access or awareness. Usually the rights of the poor infringed in remote areas of the country and the courts of remedy situated in urban areas. Kavuri \& Shao, 2017identify that distance to courts, cost of legal assistance, excessive delay in finding remedies, which result in opportunity loss of business, job loss during lengthy trial period, lack of communication, and lack of understanding of official language are problems for poor in judicial process. At Pakistan level, about to 1.8 Million cases is still pending in all courts, out which 1.2 Million pending in districts courts of Punjab (Supreme Court of Pakistan, 2014, p. 96).

As when right of a person is violated, it demands a remedy against this violation. Any delay or lack of remedy pushes him into the situation where he adopts some illegal means to get this remedy. Therefore, it is necessary to find out the causes of multi-dimensional poverty; either it is the cause of poor planning or problem in identification of its determinants. The purpose of this research is to highlight the injustice as dimension of poverty. Furthermore, this research will also look into the causes of judicial poverty, and would try to find out whether injustice is a cause of economic poverty or whether economic poverty creates injustice?

\subsection{Problem Statement 2}

World Justice Report, 2019; United Nation, 2018states that everyone is entitled to all the rights and freedoms of choice. Social justice is a standard for institutional accountability; which involves equality of rights, opportunities and equity in living conditions, access to knowledge, and health services along with fair civic and political participation of the people(Saguin, 2018).

In summarized way poverty is morally and officially unacceptable everywhere in the world, where some people are wealthy and enjoy the luxury life styles while the majority of their fellows are not provided the human dignity and minimum subsistence. All major religions faiths of the world address that poverty is morally distasteful(D. K. Sen, 2005, p. 2). There are a lot of policies and efforts at local and international level, including foreign aid in the name of the poor, the perseverance of poverty in poor countries is a fraud against the international community. The philosophical question is why after achieving so much technological achievements, within 
significant growth, clear rise in external public debt as well as in its budgetary expansion the problem has not been solved. Is it a theoretical gap of definition and modeling the impact of inefficient economic policy or planning or is it an impact of lack of empowerment or justice poverty that is the root cause of all other dimension.

\subsection{Research Questions 3}

The research questions pertaining to the topic of my study are:

1. What are the dimensions of poverty in Pakistan?

2. Whether injustice is a cause of economic poverty or economic poverty creates injustice?

\subsection{Research Objectives 4}

Following is the research objectives of my study:

1. To identify the injustice as dimension of poverty and to investigate either injustice is a cause of poverty or poverty creates injustice.

\subsection{Significance of the Study 5}

The significance of this research would be for (a) macro-economic policy maker's especially economic, health, education, and legal policy makers in Pakistan. This research will be a guideline of directions for the policy enforcers in Pakistan; (c) Stake holders in different dimensions of poverty and (e) for future researchers in the field of institutional, social and poverty related issues as well as (f) for the poor people themselves.

\section{Review of Literature 1}

Santos \& Ura, 2008, p. 12uses income approach to measure poverty based on thinking that income provides money to satisfy and fulfill human needs, but assumption of holding equal access to income is not applicable. Poverty cannot be limited to only income and consumption approach; it is multi-dimensional phenomena and requires its measurement in multiple ways; this view makes poverty as multidimensional phenomenon and income is consider as a dimension of poverty(Bourguignon \& Morrisson, 2002; Khan \& Akram, 2018). United Nation, 2012, p. 35 suggested some relative measures and different indices that adds or substitute for measurement of poverty. Consequently, the poverty measurement field is littered with various measures, each assessing a particular dimension of poverty and has its own impact and consequences.

Education is considered a tool to eradicate or overcome poverty, as educated person will earn more income and reduce the poverty. Ballon \& Duclos, 2015, p. 12measure the educational poverty by indicators of children educational gap, household head education, availability of public transport, number of children attending school and school quality by applying Alkire Foster methodology. In this methodology, a person falls in educational poverty, if he is illiterate and child/teenager is poor if he is not attending school. Alkire, 2007, p. 8measures the educational poverty with the help of indicators, school attendance, information on school enrolments (current or ever) as well, however, due to many missing values in the school enrollment variables she limits the enrolment with children aged six to fourteen years. Education level is most important factor in development of nations and economy. In discussion of education poverty, the minimum standard is considered as ability to read and write. Educational poverty is associated with the education level of household head, as if the head of a family is educated then his family will be more educated(Alkire \& Seth, 2008)

In this regard, access to basic health facilities, nutrition, child mortality, assisted delivery, unmet medical needs, are considered as measure of health poverty(Alkire, Roche, Seth, \& Sumner, 2015). Another dimension considered in literature is housing condition also mentioned as living standard. A household said to be poor if he deprives from appropriate housing facilities(Alkire \& Jahan, 2018). Mahoozi, 2015used indicators to measure housing condition by overcrowding (more than three people per room), housing facility shared (common washroom), consumption of electricity, condition of walls, floor, availability of computer, internet, access to roads, house size (one room house), construction material, decent toilet, availability of toilet and access to sanitation. His findings show that $50 \%$ in urban Punjab lives in one room house and construction material of wood/bamboo, 79 million people lack a decent toilet, 26 per cent households do not have any toilet; only $25 \%$ have access to sanitation. Here the lack of sanitation facility and water pollution creates many problems and are causes of chronic diseases, which increase the financial burden on poor families. Overcrowding and sharing of housing facility (small size of houses), quality of construction material, consumption of electricity, access to road, availability of computer and Internet also demonstrate the multi-dimensional poverty(Alkire et al., 2015).

Economic poverty which deprives the poor from basic needs becomes more worst when there is un-equitable justice system in country(Kavuri \& Shao, 2017; Saguin, 2018) In such situation a person whose basic rights are violated have to bear some cost in receiving the remedy against this violation, this extra burden may put him into economic poverty and deprive him to accessing the basic need fulfilled by financial sources. United Nation, 2012 concluded that in developed and developing countries poor due to their social status unable to claim their rights, they hardly decide to access the court due to discriminatory behavior of the officials, fear of reprisal and sanction 
from powerful groups due to fear of further corruption and exploitation, legal status in terms of housing, registration and immigration; these entire factors are cause of increase in economic poverty. In human right perspective, poverty is human condition of deprivation of choices, security, resources, power of enjoyment, adequate standard of living, other civil, economic, political, cultural and social rights. Access to justice and protection of basic rights plays a crucial role in all parts of human aspects; to overcome the judicial poverty, enforcement of these laws is crucial(United Nation, 2012).

Existence of judicial facilitation centers is situated in urban areas; this physical distance can be covered only with the help of finance to pay transportation and opportunity cost of travelling; which are causes of economic poverty. When an individual has to go to court for administration of justice, there are some direct and indirect cost in process of administration of justice. These costs must be paid in initiating the judicial process for seeking remedy against the violation of basic rights. United Nation, 2012suggested the factors cost of stamp duties, telephone calls, transportation cost, cost of legal assistance, lack of judicial review, pre-trial detention, inadequate capacity are considered as measure of judicial dimension of poverty and related cost in judicial processing is a cause of economic poverty.

Other factors like legal fee, opportunity loss, excessive delay, several legal documentary requirements, lack of poor infrastructure, and available budget are causes of injustice, and concluded that judicial system require a lot of investment in form of time, which is an opportunity loss of income from job or business; which increases the financial burden on poor. National Integrity System, 2014 in its annual report shows that corruption is a root cause of week judicial process; poor people due to extra burden of corruption do not go through judicial process for the violation of their basic rights. Combrinck \& Wakefield, 2009 declared illiteracy and language problem as hurdles in administration of justice system. It is now widely accepted that institutions have a relevance to economic performance in any economy, so it is required to make institutions powerful for the survival of economic growth. So, there is only one way to defeat the poverty is protection of basic rights or equal access to justice (United Nation, 2012).

\subsection{Research Gap 2}

Theory defines Absolute Poverty in its economic sense as income levels less than minimum acceptable consumption levels and defines Relative Poverty as more deprivation levels in comparison to other relatively less depravation levels among the absolute poor. Theory also includes powerlessness to lack of money as a measurement of poverty and devised formula for measurement of multidimensional poverty. However, not all these definitions and formulas include injustice (lack of justice) as a means of measurement of Poverty in an economy. This gap would be filled by current research.

In the dearth of literature, there is extensive work on defining and measurement of poverty, in its classical definition as well as in its multidimensional approach, but still there is a gap of considering access to justice or institutional justice as a dimension of poverty. Therefore, this study will consider access to justice as part of poverty, and measure it. In Pakistan, multidimensional poverty is measured; by considering, three dimensions health, education, and living standards but does not include injustice or lack of justice as a variable (United Nation, 2016). This research will include injustice or lack of access to justice as a dimension of multi-dimensional poverty, furthermore, also fill the gap in the current literature by measuring poverty in injustice approach.This study will also extend the scope of Multi-Dimensional Poverty by considering access to justice as a dimension of poverty.

\section{Research Methodology 1}

\subsection{Theoretical Framework 2}

Previous studies discussed the poverty measurement methods in uni-dimensional and multi-dimensional context. In uni-dimension poverty is measured by income approach, a person is mentioned as poor if his income is less than poverty line(Alkire \& Santos, 2014). In Multi-Dimensional measure, poverty is measured by different dimensions, a person is identified as poor if he is deprived in more than one dimension(Chen et al., 2019). Theoretical perspective of this study is the concept of capability approach introduced by(A. Sen, 1976).Hypotheses of study was that poverty arises when people lack key capabilities and so have inadequate income, low level of education, poor health, insecurity and lack of confidence. This theory later on applied by Foster, Greer and Thorbecke in 1984, named as FGT approach(Alkire \& Santos, 2014). Further, extended by Alkire-foster in 2010 labeling as AF counting approach, and applied on more than hundred developing countries by OPHI (Oxford Poverty Human Index) a blog of Oxford University(Alkire et al., 2015). In Pakistan Alkire applied it in 2016 considering three dimensions; health, education and living standard along with ten indicators(Idrees, 2017; United Nation, 2016)

Judicial poverty is root cause to measure other dimensions of poverty; therefore, it is necessary to include injustice as a dimension of poverty for drawing an adjusted poverty line. This research will focus on to include injustice as dimension of poverty along with other dimension of education, health and housing condition.It is the responsibility of the Government to provide protection to fundamental rights, to shapes how ordinary people 
navigate their problems related to housing, health and education, in legal aspect, these problems impact people's ability to participate in the economy. Therefore, it is necessary to understand the people's legal needs and experience about access to justice that provides important insights to design policies that foster the economic development and growth. it recognized that access to justice is foundation to economic and social development, and inability to resolve legal problems reduce the economic opportunity, undermines the human potential, reinforces the poverty trap. This view has also been endorsed by the United Nations, as the inclusion of Target 16.3 in the Sustainable Development Goals (SDGs). Therefore, it is mandatory to focus, how to resolve the legal issues, so the quick and rapid justice is available for all.

\subsection{Methodology 3}

This study will extend the scope of poverty measurement by adding injustice as a new dimension of poverty. Alkire \& Jahan, 2018defined and measured health, education and housing condition as the dimensions of poverty in Pakistan and concluded that $39 \%$ population is multi-dimensionally poor. This study will identify the statistics about injustice, and suggest to use injustice as dimension of poverty. This study will use the secondary data for the comparison and portray the position of judicial poverty or justice statistics. This data set was collected by WJP World Justice Project for the calculation judicial statistics(World Justice Project, 2018). This data set is collected nine factors divided into 47 sub-factor, these factors were decided by consultation with academic's experts, practitioners, and community leaders from respective countries. This data set in this report are built from 126 countries by assessing more than 120000 households and 3800 legal experts, collected data was transformed into 500 variables. The reliability of data is that outliers and suspicious data excluded by Z-score method. The Index methodology used has its strengths is the inclusion of both expert and households, approaches the measures by various angles, reduce possible bias, and finally, it relies on statistical test of Z-score.

For the comparison and elaborate the need of focusing on judicial problems, the secondary data obtained from the survey of 45 countries selected from different regions is used. The survey was conducted to answer the following questions, how ordinary people deal with their legal issues, what are their most common legal conflicts, what is their assessment about formal and informal resolution processes, and to know the experiences of people who were unable to resolve their problem. So the collected data is appropriate to meet the objective of this study, the captured data shows the indicators on legal needs and representing the voice of more than 46,000 people in 45 countries. In this research the comparison of collected data will be analyzed to identify the importance and need to include injustice as a dimension of poverty(Alkire \& Jahan, 2018).

\section{Results and Discussion 1}

The discussion portion of this study is compiled in two segments, in first segment the data on need and access to justice will be compared, while in second part the World Justice Index WJI (an internationally derived index for justice process) will be compared.

\subsection{Discussion on Data about Legal and Public Access to Justice 2}

Objective of this study is to mention and highlight the needs to focus on judicial process of society, and to take into account the injustice as a dimension of poverty. According to SDGs, it is important to reduce or eliminate the poverty in all its dimensions(Ahmed et al., 2018; Alkire \& Jahan, 2018; Espinoza-delgado \& Klasen, 2018). So to meet the objective of study the judicial problems of the people are categorized into six further factors. These factors include the percentage of those people who involved in litigation process, persons involved in litigation and suffered in violence by one party, the process they adopt for resolution, status of legal problem, and any kind of hardship faced after or during the litigation process. Here the five indicators have been selected from world justice process, to highlight the need to focus on judicial mechanism of a country. These indicators are summarized in following table: 
Table 1. Data from OECD Countries

\begin{tabular}{|c|c|c|c|c|c|c|c|c|c|c|}
\hline & & T.C & V. & Actio & Inaction & Statu & f Prob & & & H.S \\
\hline 1 & Afghanistan & 0.58 & 0.32 & 0.37 & 0.63 & 0.72 & 2.62 & 0.12 & 0.75 & 0.43 \\
\hline 2 & Austeria & 0.76 & 0.05 & 0.14 & 0.08 & 0.68 & 9.68 & 0.13 & 0.64 & 0.43 \\
\hline 3 & Bosnia & 0.31 & 0.05 & 0.13 & 0.87 & 0.69 & 7.74 & 0.26 & 0.61 & 0.44 \\
\hline 4 & Brazil & 0.69 & 0.04 & 0.13 & 0.87 & 0.68 & 5.85 & 0.12 & 0.77 & 0.28 \\
\hline 5 & Burkina Faso & 0.70 & 0.06 & 0.09 & 0.91 & 0.48 & 3.25 & 0.11 & 0.77 & 0.24 \\
\hline 6 & Canada & 0.52 & 0.08 & 0.17 & 0.83 & 0.64 & 10.59 & 0.11 & 0.66 & 0.50 \\
\hline 7 & Chile & 0.44 & 0.06 & 0.13 & 0.87 & 0.79 & 7.15 & 0.05 & 0.84 & 0.23 \\
\hline 8 & Cote d'Ivoire & 0.42 & 0.09 & 0.10 & 0.90 & 0.62 & 1.70 & 0.15 & 0.65 & 0.40 \\
\hline 9 & Czech Republic & 0.80 & 0.07 & 0.16 & 0.84 & 0.69 & 11.73 & 0.12 & 0.65 & 0.49 \\
\hline 10 & Denmark & 0.56 & 0.02 & 0.11 & 0.89 & 0.61 & 5.45 & 0.05 & 0.77 & 0.33 \\
\hline 11 & Estonia & 0.73 & 0.05 & 0.11 & 0.89 & 0.67 & 6.54 & 0.09 & 0.73 & 0.46 \\
\hline 12 & Ethiopia & 0.75 & 0.26 & 0.29 & 0.71 & 0.39 & 5.40 & 0.26 & 0.53 & 0.66 \\
\hline 13 & Finland & 0.69 & 0.05 & 0.07 & 0.93 & 0.68 & 12.81 & 0.09 & 0.66 & 0.41 \\
\hline 14 & Georgia & 0.34 & 0.04 & 0.05 & 0.95 & 0.50 & 11.80 & 0.11 & 0.79 & 0.22 \\
\hline 15 & Greece & 0.89 & 0.03 & 0.21 & 0.79 & 0.51 & 12.51 & 0.35 & 0.71 & 0.54 \\
\hline 16 & Hong Kong & 0.14 & 0.01 & 0.06 & 0.94 & 0.96 & 3.38 & 0.02 & 0.92 & 0.07 \\
\hline 17 & Honduras & 0.18 & 0.09 & 0.14 & 0.86 & 0.70 & 3.50 & 0.22 & 0.77 & 0.45 \\
\hline 18 & Hungary & 0.29 & 0.02 & 0.08 & 0.92 & 0.79 & 9.91 & 0.16 & 0.81 & 0.26 \\
\hline 19 & Indonesia & 0.26 & 0.02 & 0.08 & 0.92 & 0.79 & 1.98 & 0.04 & 0.90 & 0.08 \\
\hline 20 & Italy & 0.75 & 0.04 & 0.14 & 0.86 & 0.68 & 13.62 & 0.19 & 0.62 & 0.41 \\
\hline 21 & Kazakhstan & 0.27 & 0.04 & 0.12 & 0.88 & 0.75 & 7.00 & 0.26 & 0.72 & 0.41 \\
\hline 22 & Lebanon & 0.49 & 0.10 & 0.19 & 0.81 & 0.67 & 6.05 & 0.21 & 0.68 & 0.40 \\
\hline 23 & Macedonia & 0.47 & 0.04 & 0.13 & 0.87 & 0.52 & 26.00 & 0.26 & 0.55 & 0.46 \\
\hline 24 & Madagascar & 0.36 & 0.24 & 0.19 & 0.81 & 0.67 & 6.50 & 0.22 & 0.62 & 0.61 \\
\hline 25 & Malawi & 0.73 & 0.10 & 0.08 & 0.92 & 0.46 & 4.65 & 0.16 & 0.69 & 0.54 \\
\hline 26 & Malaysia & 0.71 & 0.04 & 0.14 & 0.86 & 0.66 & 3.14 & 0.11 & 0.78 & 0.32 \\
\hline 27 & Mexico & 0.38 & 0.09 & 0.11 & 0.89 & 0.66 & 6.83 & 0.16 & 0.68 & 0.49 \\
\hline 28 & Mongolia & 0.64 & 0.05 & 0.04 & 0.96 & 0.62 & 4.45 & 0.29 & 0.71 & 0.47 \\
\hline 29 & Nepal & 0.84 & 0.05 & 0.05 & 0.95 & 0.70 & 5.19 & 0.08 & 0.80 & 0.19 \\
\hline 30 & New Zealand & 0.63 & 0.05 & 0.12 & 0.88 & 0.69 & 7.83 & 0.11 & 0.71 & 0.46 \\
\hline 31 & Nicaragua & 0.31 & 0.09 & 0.14 & 0.86 & 0.69 & 7.16 & 0.16 & 0.70 & 0.47 \\
\hline 32 & Norway & 0.58 & 0.03 & 0.08 & 0.92 & 0.65 & 8.09 & 0.12 & 0.61 & 0.41 \\
\hline 33 & Pakistan & 0.85 & 0.04 & 0.14 & 0.86 & 0.33 & 2.57 & 0.19 & 0.73 & 0.39 \\
\hline 34 & panama & 0.33 & 0.07 & 0.21 & 0.79 & 0.72 & 5.40 & 0.17 & 0.82 & 0.38 \\
\hline 35 & Portugal & 0.81 & 0.04 & 0.14 & 0.86 & 0.68 & 23.93 & 0.19 & 0.68 & 0.45 \\
\hline 36 & Senegal & 0.71 & 0.04 & 0.05 & 0.95 & 0.44 & 6.00 & 0.07 & 0.67 & 0.28 \\
\hline 37 & Serbia & 0.50 & 0.04 & 0.14 & 0.86 & 0.60 & 8.58 & 0.22 & 0.63 & 0.42 \\
\hline 38 & Singapore & 0.50 & 0.07 & 0.13 & 0.07 & 0.67 & 8.53 & 0.15 & 0.65 & 0.45 \\
\hline 39 & Slovenia & 0.42 & 0.05 & 0.20 & 0.80 & 0.62 & 30.60 & 0.15 & 0.68 & 0.41 \\
\hline 40 & Sri Lanka & 0.25 & 0.07 & 0.15 & 0.85 & 0.45 & 6.88 & 0.10 & 0.61 & 0.37 \\
\hline 41 & Tunisia & 0.46 & 0.05 & 0.14 & 0.86 & 0.51 & 11.35 & 0.10 & 0.50 & 0.30 \\
\hline 42 & Ukraine & 0.42 & 0.05 & 0.07 & 0.93 & 0.68 & 9.93 & 0.30 & 0.67 & 0.37 \\
\hline 43 & United Kingdom & 0.63 & 0.03 & 0.07 & 0.93 & 0.72 & 8.96 & 0.09 & 0.62 & 0.40 \\
\hline 44 & United States & 0.48 & 0.13 & 0.23 & 0.77 & 0.53 & 5.88 & 0.09 & 0.70 & 0.50 \\
\hline 45 & Vietnam & 0.14 & 0.07 & 0.09 & 0.91 & 0.78 & 7.67 & 0.07 & 0.69 & 0.40 \\
\hline
\end{tabular}

4.2 Incidence of Legal Problems 3

This category shows the percentage of those who overall involved in litigation process in the last two years, disaggregated by gender. Overall results show that Pakistan is at second position among the selected 45 countries. Statistics show that top five countries have 80 to 89 percent of people involved in legal problem, the figure for Pakistan is $85 \%$, second in the top five countries. The maximum score in this category is 89 percent for Greece, however according the culture and geographical position, the Greece has high percentage of registered cases due 
to burden of refugees and illegal migrants, but the position for Pakistan is alarming in current scenario, and requires much attention from policy makers and Government toward judicial sector.

\subsection{Violence 4}

This indicator shows proportion of those who have reported that one of the other party has resorted some physical violence during litigation process. The term physical violence shows the use of political power and other form of pressure imposed on poor or weak party. It is observed that in Pakistan four percent persons have been reported by physical violence. This percentage is much higher in those countries, which have political instability and weak law and order situation like Afghanistan and Ethiopia.

\subsection{Action or Inaction 5}

Shows the percentage of those who themselves or somebody acting on their behalf involve any institution or person to mediate in problem, or to resolve the problem, or actor to adjudicate. This indicator also includes taking the legal problem to police, to court or tribunal, a government office or authority, a third party either religious or community leader, or a formal complaints or appeal process. Statistics reveals that in Pakistan the involvement of third party in litigation process is not much better, as involvement of third person especially the relevant court or authorized government institution is the legal way to get remedy. Low percentage of third party involvement raises some question like, either people have not trust on these institutions for their relief or these institutes are professionally weak and unable to resolve public problems.

\subsection{Satus of Legal Problems 6}

The fourth indicator used in this study to compare and highlight the judicial statistics is the status of problem. This indicator has mentioned four sub factors, and these sub factors shows logical relation among themselves. These four sub factors include the overall status of complaints either it is resolved or not, duration to resolve the issue, percentage of getting financial difficulties and satisfaction about judicial process. Statistics revealed that the countries who have highest ratio of complaints resolved, shows optimum level of satisfaction and vice versa. This relation have logical and theoretical base as getting the resolved complaints will results in satisfaction status. Pakistan is lowest $\mathrm{n}$ this ranking, and has only $33 \%$ complaints resolved, which on the other hand means $67 \%$ of registered complaints are under litigation process. Furthermore the countries having higher economic position like GDP and fall in higher income level have maximum ratio of complaints resolved and higher satisfaction level.

\subsection{Hardship 7}

This indicator is used in this study because when a person gets involvement in some issue or problem, this will result in extra burden on him. The hardship level shows that during litigation process a person may suffer in stressrelated illness, loss of employment, or need to relocate, the breakdown of a relationship, and problems with addiction like alcohol or drugs. The statistics shows that in Pakistan almost 39\% people suffer in any kind of hardship. This ratio is much higher in more liberal as well as poor economic countries. This indicator has four sub factors like illness, relation brake, loss of employment and addiction of drugs. Ethiopia has optimum involvement in hardship problem and shows $66 \%$ of person suffered in hardship, among sub factors $42 \%$ or people in litigation process suffer in any kind of disease. These statistics also mention that litigation process also a cause of stress and illness, which ultimately result in raising the poverty in other dimensions like health and economic poverty.

\subsection{World Justice Index (The Rule of Law) 8}

World Justice Project presented the summarized definition of rule of law as "effective rule of law reduces corruption, combats poverty and disease, and protects people from injustices large and small". It is the base for justice communities, peace, underpinning development, opportunity, and respect for fundamental rights. In tradition concept, the rule of law was the domain of judges and lawyers, but in modern view the issues of safety, justice, rights and governance are the stakeholders in the rule of law.

The rule of law has two principles: first measures whether the law imposes limits on the exercise of power by the state and its agents, second principle measures whether the state imposed or limitizes the basic duties towards its population, as well as individuals and private entities. The first principle is measured in first four factors, while second principle measured in factor five to eight. The Index recognizes that a system of law that unable to respect human rights under international law is at best "rule by law" and cannot be called a rule of law system. 
Table 2. World Justice Process

\begin{tabular}{|c|c|c|c|c|c|c|c|c|c|c|}
\hline S. No No & Country & WJI & C.G.P & A.C & O.G & F.R & O. S & R. E & C. $\mathbf{J}$ & C.J \\
\hline 1 & Afghanistan & 0.35 & 0.43 & 0.28 & 0.37 & 0.40 & 0.30 & 0.35 & 0.38 & 0.28 \\
\hline 2 & Austria & 0.82 & 0.84 & 0.84 & 0.72 & 0.85 & 0.90 & 0.84 & 0.78 & 0.80 \\
\hline 3 & Bosnia and Herzegovina & 0.53 & 0.45 & 0.44 & 0.47 & 0.59 & 0.76 & 0.49 & 0.51 & 0.50 \\
\hline 4 & Brazil & 0.53 & 0.56 & 0.45 & 0.62 & 0.55 & 0.65 & 0.52 & 0.55 & 0.35 \\
\hline 5 & Burkina Faso & 0.50 & 0.55 & 0.44 & 0.46 & 0.57 & 0.62 & 0.46 & 0.46 & 0.47 \\
\hline 6 & Canada & 0.81 & 0.85 & 0.83 & 0.81 & 0.83 & 0.91 & 0.81 & 0.70 & 0.73 \\
\hline 7 & Chile & 0.68 & 0.72 & 0.70 & 0.72 & 0.73 & 0.68 & 0.65 & 0.63 & 0.57 \\
\hline 8 & Cote d'Ivoire & 0.46 & 0.41 & 0.37 & 0.37 & 0.46 & 0.68 & 0.52 & 0.52 & 0.38 \\
\hline 9 & Czech Republic & 0.73 & 0.73 & 0.64 & 0.66 & 0.78 & 0.90 & 0.70 & 0.70 & 0.70 \\
\hline 10 & Denmark & 0.90 & 0.95 & 0.95 & 0.86 & 0.92 & 0.93 & 0.90 & 0.87 & 0.83 \\
\hline 11 & Estonia & 0.81 & 0.84 & 0.80 & 0.80 & 0.83 & 0.89 & 0.79 & 0.80 & 0.71 \\
\hline 12 & Ethiopia & 0.39 & 0.33 & 0.46 & 0.28 & 0.29 & 0.64 & 0.36 & 0.41 & 0.33 \\
\hline 13 & Finland & 0.87 & 0.92 & 0.89 & 0.87 & 0.92 & 0.92 & 0.84 & 0.80 & 0.84 \\
\hline 14 & Georgia & 0.61 & 0.57 & 0.70 & 0.59 & 0.62 & 0.78 & 0.56 & 0.54 & 0.52 \\
\hline 15 & Greece & 0.62 & 0.69 & 0.57 & 0.61 & 0.66 & 0.72 & 0.59 & 0.58 & 0.51 \\
\hline 16 & Hong Kong SAR, China & 0.77 & 0.65 & 0.84 & 0.75 & 0.66 & 0.93 & 0.82 & 0.77 & 0.71 \\
\hline 17 & Honduras & 0.40 & 0.37 & 0.34 & 0.42 & 0.41 & 0.60 & 0.40 & 0.41 & 0.26 \\
\hline 18 & Hungary & 0.53 & 0.41 & 0.51 & 0.46 & 0.58 & 0.91 & 0.47 & 0.46 & 0.48 \\
\hline 19 & Indonesia & 0.52 & 0.66 & 0.38 & 0.54 & 0.52 & 0.70 & 0.55 & 0.44 & 0.37 \\
\hline 20 & Italy & 0.65 & 0.71 & 0.63 & 0.63 & 0.73 & 0.74 & 0.59 & 0.56 & 0.64 \\
\hline 21 & Kazakhstan & 0.52 & 0.43 & 0.47 & 0.47 & 0.46 & 0.78 & 0.51 & 0.59 & 0.44 \\
\hline 22 & Lebanon & 0.47 & 0.52 & 0.39 & 0.44 & 0.52 & 0.64 & 0.44 & 0.44 & 0.38 \\
\hline 23 & Macedonia, FYR & 0.54 & 0.47 & 0.47 & 0.49 & 0.57 & 0.79 & 0.48 & 0.57 & 0.47 \\
\hline 24 & Madagascar & 0.43 & 0.44 & 0.26 & 0.46 & 0.47 & 0.71 & 0.35 & 0.40 & 0.34 \\
\hline 25 & Malawi & 0.51 & 0.56 & 0.42 & 0.43 & 0.59 & 0.68 & 0.45 & 0.54 & 0.45 \\
\hline 26 & Malaysia & 0.55 & 0.54 & 0.58 & 0.38 & 0.48 & 0.77 & 0.53 & 0.60 & 0.54 \\
\hline 27 & Mexico & 0.45 & 0.47 & 0.29 & 0.61 & 0.54 & 0.57 & 0.46 & 0.40 & 0.29 \\
\hline 28 & Mongolia & 0.55 & 0.54 & 0.44 & 0.51 & 0.58 & 0.77 & 0.49 & 0.54 & 0.50 \\
\hline 29 & Nepal & 0.53 & 0.60 & 0.43 & 0.52 & 0.54 & 0.72 & 0.50 & 0.47 & 0.44 \\
\hline 30 & New Zealand & 0.82 & 0.85 & 0.87 & 0.81 & 0.80 & 0.89 & 0.85 & 0.78 & 0.72 \\
\hline 31 & Nicaragua & 0.40 & 0.27 & 0.35 & 0.38 & 0.39 & 0.70 & 0.45 & 0.41 & 0.28 \\
\hline 32 & Norway & 0.89 & 0.94 & 0.94 & 0.88 & 0.90 & 0.93 & 0.87 & 0.85 & 0.83 \\
\hline 33 & Pakistan & 0.39 & 0.52 & 0.32 & 0.45 & 0.38 & 0.36 & 0.38 & 0.38 & 0.35 \\
\hline 34 & Panama & 0.52 & 0.53 & 0.42 & 0.59 & 0.62 & 0.68 & 0.51 & 0.49 & 0.31 \\
\hline 35 & Portugal & 0.71 & 0.79 & 0.72 & 0.67 & 0.79 & 0.79 & 0.64 & 0.69 & 0.60 \\
\hline 36 & Senegal & 0.55 & 0.58 & 0.54 & 0.44 & 0.60 & 0.69 & 0.55 & 0.56 & 0.45 \\
\hline 37 & Serbia & 0.50 & 0.40 & 0.44 & 0.47 & 0.56 & 0.78 & 0.47 & 0.50 & 0.38 \\
\hline 38 & Singapore & 0.80 & 0.69 & 0.91 & 0.66 & 0.69 & 0.93 & 0.87 & 0.83 & 0.78 \\
\hline 39 & Slovenia & 0.67 & 0.65 & 0.66 & 0.65 & 0.73 & 0.89 & 0.64 & 0.63 & 0.55 \\
\hline 40 & Sri Lanka & 0.52 & 0.55 & 0.46 & 0.50 & 0.54 & 0.70 & 0.49 & 0.47 & 0.45 \\
\hline 41 & Tunisia & 0.53 & 0.60 & 0.47 & 0.50 & 0.56 & 0.63 & 0.53 & 0.49 & 0.43 \\
\hline 42 & Ukraine & 0.50 & 0.46 & 0.33 & 0.55 & 0.61 & 0.73 & 0.42 & 0.54 & 0.37 \\
\hline 43 & United Kingdom & 0.80 & 0.84 & 0.83 & 0.80 & 0.82 & 0.85 & 0.82 & 0.73 & 0.75 \\
\hline 44 & United States & 0.71 & 0.73 & 0.74 & 0.77 & 0.72 & 0.76 & 0.73 & 0.64 & 0.63 \\
\hline 45 & Vietnam & 0.49 & 0.45 & 0.40 & 0.46 & 0.46 & 0.77 & 0.45 & 0.45 & 0.46 \\
\hline
\end{tabular}

Table two shows the summarized statistics for Rule of Law Index report for the year 2018 (World Justice Report, 2019). The main discussion point in this part is Rule of law Index, which has eight sub-factors, these subfactors are overall predictors for the WJI. The table below shows the overall scores and rankings of the selected 45 countries WJI (Rule of Law Index or World Justice Index) in alphabetical order. Scores range from 0 to 1, with 1 indicating the strength of the rule of law and 0 for weakness of law. Here is the summarized over view of the factors, which are the determinants of rule of law index.

Factor one is constraints on Government power in both forms constitutional and institutional, purpose of these 
constraints is to lemmatize the power of government officials and agent to make them accountable under the law. Factor two is the absence of corruption in government in its three forms: misappropriation of public resources, improper influence by public or private interests and bribery. These three forms of corruption are considered with respect to military, police, judiciary, legislature and government officers in the executive branch. Factor 3 measures the extent to which a government empowers people and shares information, to hold the government accountable. Factor 4 consider that a system of positive law that unable to respect human rights according to international law is at best "rule by law," cannot be called a rule of law system. Factor 5 discusses the how well a society guarantees the security of persons and property, as it is the precondition to realize the rights and freedoms that the rule of law seeks to advance. Factor 6 examines the implementation and enforcement of regulation fairly and effectively, in both legal and administrative within and outside of the government. Factor 7 measures the access to civil justice system by an ordinary person to resolve its grievances effectively and peacefully. Factor 8 is about to country's criminal justice system, access to criminal justice considers the entire system, including the lawyers, police, judges, prosecutors, and prison officers. All these factors are the back bone for a peaceful society, and represent the actual position of rule of law. The overall Rule of Law index is the average of the scores of all these factors.

Statistics shows that the countries which are revealing the optimum level of Rule of Law index are those who have better economic position and higher per capita income. Here the underpinning question has verified that there is some relation between economic condition and poverty. In other words, it is necessary to find the answer of question, either the injustice is the cause of poverty or poverty creates injustice. The relevant range of index is from 0 to 1 , lower the score will show the weakness of rule of law index. Here it is observed that countries show the score in descending order parallel to the order of their per capita income, for example maximum score $90 \%$ is assigned to Denmark, on the other hand this country has maximum per capita income. As for Pakistan, fall in lowest position, $3^{\text {rd }}$ from bottom side, also have similar ranking in per capita income. It is observed that involvement in litigation process for the seeking of remedy against the violation of basic fundamental rights puts some extra financial burden, which pushes the person into economic poverty.

\section{Conclusion 1}

This study reveals that people in all countries have experienced some legal problems, regardless of their socioeconomic status and gender, however results vary by country to country. Some of effected people approach to lawyer and courts, while some are unable to register their case for claim due to different reasons(World Justice Report, 2019).World Justice Project, 2018showed that 80 to 89 percent of peoples involved in judicial process belong to top five countries, Pakistan is at second position among the selected 45 countries. Statistics show that $85 \%$ people in Pakistan involved in litigation process, this is alarming position in current scenario, and require much attention from policy makers and Government toward judicial sector. Out of these, $4 \%$ reported the existence of some kind of physical violence during litigation process; the score is much higher in politically instability countries. Public trust on Government institution shows the trust of people on their government, but this indicator is also poor in Pakistan, only 14 percent people use government institutes as $3^{\text {rd }}$ party in their disputes resolution. Justice should be quick in society, as it is maxim in law that "justice delayed is justice denied", it is also the representative of public satisfaction on judiciary. Pakistan is lowest in this ranking, and have only $33 \%$ complaints resolved, which on the other hand means $67 \%$ of registered complaints are under litigation process. On the other hand, involvement in litigation process is the cause of many hardships likely stress and illness, and ultimately the cause of health poverty. The statistics shows that in Pakistan almost 39\% person suffer in any kind of hardship. This study also reveals that, much proportion of legal problems remain unresolved, some of them unable to fully settle the issue, some of them ultimately give up or move away. The second aspect of comparison shows that the countries with optimum level of Rule of Law index are those who have better economic position and higher per capita income. Here the underpinning question has been answered that there is some relation between economic condition and injustice(Saguin, 2018)(Ahmed et al., 2018). In other words, it is necessary to find the answer of question, either the injustice is the cause of poverty or poverty creates injustice. Countries with maximum score for rule of law show the score in descending order parallel to the order of their per capita income. As for Pakistan, fall in lowest position, $3^{\text {rd }}$ from bottom side, also have similar ranking in per capita income. So it is concluded that to eliminate the poverty, it is prior condition to define the poverty in all its dimensions (World Justice Report, 2019). Access to justice is the fundamental right of people living in society, and is also the root cause of many other problems, so it should be included as the part of poverty when to define the poverty. A problem can only be solved, when it is defined in proper and in its complete essence.

\section{References}

Abel-smith, B., \& Townsend, P. (1965). The Poor and the poorest (No. 17).

Ahmed, S. amer, Barıs, E., S.Go, D., Lofgren, H., Osorio-rodarte, I., \& Thierfelder, K. (2018). Assessing the global poverty effects of antimicrobial resistance. World Development, 111, 148-160.

Alkire, S. (2007). a misconceived theory can kill (No. 11). 
Alkire, S., \& Jahan, S. (2018). The new global MPI 2018 : aligning with the sustainable development goals.

Alkire, S., Roche, J. M., Seth, S., \& Sumner, A. (2015). Identifying the poorest people and groups: strategies using the global multidimensional poverty index. Journal of International Development, 27(1), 362-387.

Alkire, S., \& Santos, M. E. (2014). Measuring acute poverty in the developing world : robustness and scope of the multidimensional poverty index. World Development, 59, 251-274.

Alkire, S., \& Seth, S. (2008). Measuring multidimensional poverty in India: a new proposal (No. 15).

Ballon, P., \& Duclos, J. (2015). Multidimensional poverty in Sudan and South Sudan (No. 93).

Booth, C. (1893). Life and labour of the people in london: first results of an inquiry based on the 1891 census. Journal of the Royal Statistical Society, 56(4), 557-593.

Booth, C. (1902). Life and labour of the peopple in London. In MACMILLAN AND CO. (Final, Vol. 1). New York: MACMILLAN AND CO.

Bourguignon, F., \& Morrisson, C. (2002). Inequality among world citizens : 1820 - 1992. American Economic Review, 727-744.

sChen, J., Kosec, K., \& Mueller, V. (2019). Moving to despair? Migration and well-being in Pakistan. World Development, 113, 186-203.

Combrinck, H., \& Wakefield, L. (2009). Training for police on the domestic voilance act.

Deveaux, M. (2018). Poor-Led social movements and global justice. Political Theory, 1(1), 1-28.

Espinoza-delgado, J., \& Klasen, S. (2018). Gender and multidimensional poverty in Nicaragua : An individual based approach. World Development Journal, 110, 466-491.

Fusco, A. (2003). On the definition and measurement of poverty: the contribution of multidimensional analysis. The Capability Approach: From Sustainable Development to Sustainable Freedom, (May 2003), 1-40.

Gaye, A., Klugman, J., Kovacevic, M., Twigg, S., \& Zambrano, E. (2010). Measuring key disparities in human development: the gender inequality index.

Idrees, M. (2017). Poverty in Pakistan : a region-specific analysis. The Lahore Journal of Economics, 22(Winter), $139-163$

Kavuri, A. S., \& Shao, H. (2017). The impact of social justice on economic performance (No. 18).

Khan, F. N., \& Akram, S. (2018). Sensitivity of multidimensional poverty index in Pakistan. THE PAKISTAN JOURNAL OF SOCIAL ISSUES, 1(June), 98-108.

Mahoozi, H. (2015). Gender and spatial disparity of multidimensional poverty in Iran (No. 95).

Marshal, A. (1879). Progress and poverty: an inquiry into the cause of industrial depressions and of increase of want with increase of wealth, the remedy (first). San Francisco: W.M. Hinton and Company.

Masood, M. T. (2018). Strategy for delay reduction and expeditious disposal of backlog of cases. Expeditious Disposal of Backlog of Cases, 1-35. Islamabad: The Law and Justice Commission of Pakistan.

Nations, U. (2006). Social justice in an open world: the role of the United Nations.

Neelsen, S., Limwattananon, S., Donnell, O. O., \& Doorslaer, E. Van. (2019). Universal health coverage: A ( social insurance ) job half done? World Development, 113(113), 246-258.

Organization, W. H. (2010). International workshop on housing, health and climate change : developing guidance for health -protection in the built environment - mitigation and adaptation responses.

Phoenix, D. (1998). The importance of educational research. 33(1), 1-3.

Rowntree, S. (1908). Poverty a study of town life (Second). London: MACMILLAN AND CO.

Saguin, K. (2018). Why the poor do not benefit from community-driven development: Lessons from participatory budgeting. World Development, 112, 220-232.

Santos, M. E., \& Ura, K. (2008). Multidimensional poverty in Bhutan : estimates and policy implications (No. 14).

Schwab, K. (2018). The global competitiveness report.

Sen, A. (1976). Poverty: an ordinal approach to measurement. Econometrica, 44(2), 219-231.

Sen, D. K. (2005). Economics of poverty and social justice: a brief analysis. Pakistan Economic and Social Review, $X \operatorname{LIII}(2), 213-226$.

Townsend, P. (1979). Poverty in the United Kingdom a survey of household resources and standards of living (First). Allen Lane.

Zhou, Y., \& Liu, Y. (2019). The geography of poverty : Review and research prospects. Journal of Rural Studies Journal, (January 2019), 9. 